\title{
The implications of subjective career success
}

\author{
Lorraine Dyke $\cdot$ Linda Duxbury
}

Accepted: 1 October 2010 / Published online: 23 November 2010

(C) Institut für Arbeitsmarkt- und Berufsforschung 2010

\begin{abstract}
The present study examined the relationship between employees' ability to achieve subjective success and their work attitudes. Four dimensions of subjective success were measured: fulfilling work, financial rewards, recognition, and authority. Hierarchical regression models predicting job satisfaction, commitment, and turnover were examined. Objective indicators of success (organizational level, promotions, and salary) were included as control variables along with importance scores and achievement scores for the success criteria. Results indicate that an employee's achievement of fulfilling work is the strongest predictor of their attitudes towards the job and organization. Together, the achievement of the four success criteria explained significantly more variance in attitudes than objective indicators of success or success criteria importance.
\end{abstract}

Keywords Careers - Subjective success - Employee attitudes $\cdot$ High technology

\section{Die Implikationen von subjektivem Berufserfolg}

Zusammenfassung Die vorliegende Studie untersucht den Zusammenhang zwischen subjektivem Erfolgserleben und verschiedenen Arbeitseinstellungen (Arbeitszufriedenheit, organisationale Bindung, Wechselabsicht) bei einer Stichprobe von IT-Beschäftigten. Vier Facetten subjektiven Berufserfolgs wurden gemessen: erfüllende Arbeit, Erleben

L. Dyke $(\bullet) \cdot$ L. Duxbury

Carleton University, Sprott School of Business,

1125 Colonel By Drive, Ottawa K1S 5B6, ON, Canada

e-mail: lorraine_dyke@carleton.ca

Tel.: +1-613-5202600

Fax: +1-613-5202652 finanziellen Erfolgs, Erleben von Anerkennung und Erleben von Einfluss. In hierarchischen Regressionsanalysen wurden objektive Erfolgskriterien (hierarchische Ebene, Beförderungen, Gehalt), die Wichtigkeit der vier Facetten subjektiven Berufserfolgs und das Erreichen dieser vier Facetten auf ihren Einfluss auf die drei Arbeitseinstellungen untersucht. Es zeigte sich, dass die objektiven Erfolgskriterien und die Wichtigkeit der subjektiven Kriterien keinen Einfluss hatten, während das Erreichen insbesondere erfüllender Arbeit und ferner das Erleben finanziellen Erfolgs sehr bedeutsam waren.

Schlüsselwörter Karriere · Subjektiver Erfolg • Einstellungen der Mitarbeiter · Technologie

\section{Introduction}

Success is a key outcome in careers research (Heslin 2005). Subjective success represents an individual's self-evaluation of her or his success (Gattiker and Larwood 1986; Peluchette 1993). Research suggests that subjective success is related to but broader than objective indicators of success (Abele and Spurk 2009b; Ng et al. 2005) and may include criteria such as relationships, balance, enjoyment, and recognition (Dyke and Murphy 2006; Sturges 1999).

The research done to date on subjective success focuses largely on the antecedents of subjective success and seeks to determine what makes people evaluate their careers positively (e.g. Abele and Spurk 2009b; Gattiker and Larwood 1986; Ng et al. 2005; Peluchette 1993). Very few studies have explored the link between subjective career success and key organizational attitudes. This is unfortunate as research conducted within the person-environment fit tradition (Kristof-Brown et al. 2005) would suggest that 
employees are more likely to report positive attitudes towards their work and their organization when there is a fit between their definitions of subjective career success and their career achievements. To date, however, neither the literature on person-environment fit nor the subjective success research has examined this relationship. This paper addresses this gap by exploring the impact that attainment of subjective career success has on three key employee attitudes toward their work and organization: job satisfaction, organizational commitment, and intent to turnover.

\subsection{The construct of subjective success}

Subjective success represents an individual's self-evaluation of her or his career (Gattiker and Larwood 1986; Peluchette 1993). This study is based on the assumption that to understand the relationship between subjective success and key organizational outcomes, one needs to look at two things: what individuals value in their careers (achievements may not be valued in the same way by everyone) and whether they feel that they have the opportunity within their work environment to achieve their aspirations (Gunz and Heslin 2005; Heslin 2005). This assumption is consistent with Bailyn's argument that "the subjective, internal meaning of the career must be juxtaposed with its external more objective characteristics" (1989, p. 477). This assumption is also consistent with person-environment fit theory (Caplan and Harrison 1993; Edwards 1994; Kristof 1996).

\subsection{Subjective success and work attitudes}

Organizations are likely to influence employees' achievement of subjective success in a number of ways. First, objective criteria of success such as pay, promotion, and hierarchical level are rewards that are under the control of the organization. The manner in which organizations allocate these rewards may have a significant influence on whether or not an employee feels successful. Further, other more subjective success criteria such as a sense of personal accomplishment, recognition, enjoyable work, or positive working relationships can also be influenced by organizational context (Heslin 2005). Finally, organizations can potentially influence the achievement of non-work criteria of success such as work-life balance or good health by limiting the time and energy employees have to devote to these pursuits.

The literature suggests that employees who work for organizations that understand and are able to facilitate employee subjective career success will report more positive attitudes towards work and their employer. Theoretical perspectives such as needs theories (Herzberg et al. 1959), the theory of work adjustment (Dawis and Lofquist 1984), the attraction-selection-attrition model (Schneider 1987), and self-determination theory (Deci and Ryan 2000), for example, all support the notion that employees experience more positive attitudes when there is congruence between their preferences and the features of their workplace. A meta-analysis of person-environment fit studies indicates that various types of fit (e.g. person-vocation, person-job, person-organization, person-group, and person-supervisor) are associated with positive attitudes toward work and the organization - with strong, pervasive effects noted particularly for job satisfaction, organizational commitment, and intent to turnover (Kristof-Brown et al. 2005). The present research extends this tradition by examining the impact on attitudes of the congruence between employees' success aspirations and achievements.

Job satisfaction refers to a positive evaluation of one's job (Locke 1976; Spector 1997). Meta-analytic results indicate that job satisfaction has an impact on performance (Judge et al. 2001), commitment, turnover intentions, and turnover (Tett and Meyer 1993). Job satisfaction has been used by some researchers as a proxy for subjective success (e.g. Abele and Spurk 2009a; Judge and Bretz 1994; Judge et al. 1995) but as Heslin (2005) notes, the concept of subjective success incorporates a broader time frame and a wider range of outcomes than immediate job satisfaction. Research has also found that career satisfaction and job satisfaction are distinct constructs (Erdogan et al. 2004). Job satisfaction is influenced by a variety of characteristics related to the job, the organization, and the employee (Glisson and Durick 1988). The meta-analytic results regarding person-environment fit support the notion that when the characteristics of the job or the organization match the characteristics of the employee, greater job satisfaction is likely to result (Kristof-Brown et al. 2005). Similarly, we would expect that when the characteristics of the work environment support an employee's subjective success aspirations, they will be likely to evaluate the job more positively.

Organizational commitment can be thought of as the bond between the employee and the organization (O'Reilly and Chatman 1986). Organizational commitment has a different focus than job satisfaction: "commitment emphasizes attachment to the employing organization, including its goals and values, whereas satisfaction emphasizes the specific task environment where an employee performs his or her duties" (Mowday et al. 1982, p. 28). Given that organizational commitment is conceptualized as a bond or attachment to the organization, turnover intentions can be viewed as the opposite of commitment. Meta-analytic results support the negative relationship between organizational commitment and turnover intentions (Tett and Meyer 1993). Both organizational commitment and turnover intentions are likely to be influenced by an employee's experience of subjective success. Just as person-environment fit enhances commitment and reduces turnover (Kristof-Brown 
et al. 2005), employees who believe that the organization has helped them to achieve subjective success may be more likely to view the organization favorably and to anticipate potential losses should they leave the organization.

The above review of theory and empirical findings leads us to hypothesize that:

Employees who experience greater subjective success will exhibit higher job satisfaction (H1), higher organizational commitment (H2), and lower turnover intentions (H3).

\section{Method}

\subsection{Sample and procedures}

The hypotheses were tested using survey data collected from managers and professionals in the high-technology sector in Canada. Six of the ten largest high-technology firms in Canada's National Capital Region agreed to participate in the study. All of the managers and professionals in these firms $-4,100$ in total - were invited to participate in the survey. Questionnaires were distributed and collected through the firms' internal mail services but forwarded unopened to the researchers. As responses were anonymous, no followup was undertaken for nonrespondents.

Responses were received from 1,509 employees (37\%). The majority of respondents were men (67\%) and the average age was 36 . Post-secondary education was almost universal (97\%) with most holding a university degree (66\%). A majority of respondents were married (73\%) and had children $(50 \%)$.
Respondents had an average of 12 years of work experience - 9 years of that in the high-tech sector. On average, they had worked for four different employers, spent over five years in their current organization and two in their current position. A majority (58\%) worked in product development, engineering, or programming. Others worked in technical or customer support (13\%), marketing and sales $(11 \%)$, or other functions $(18 \%)$. Most respondents were in professional or technical roles $(62 \%)$, first-level management $(13 \%)$ or middle management $(14 \%)$, with the remainder in either senior management $(3 \%)$ or other nonmanagement roles $(7 \%)$. Just under a third (31\%) managed the work of others. Respondents worked an average of $46 \mathrm{~h}$ per week.

\subsection{Measures}

Each of the focal constructs was measured using multi-item, 5-point scales. In addition to measuring the importance and achievement of subjective success criteria, and the three hypothesized attitudinal outcomes, data were collected on three measures of objective success - level, salary, and promotions - to serve as control variables.

\subsubsection{Subjective success}

Fifteen criteria were selected to represent subjective success based on an examination of the qualitative (Dyke and Murphy 2006; Sturges 1999) and quantitative (Gattiker and Larwood 1986; Nabi 2001) research literature on how people define success. The success criteria examined in this study (see Table 1) include a mix of traditional objective criteria such as increasing financial rewards and moving through po-
Table 1 Success items and factors

\begin{tabular}{|c|c|c|c|c|c|c|}
\hline \multirow{2}{*}{$\begin{array}{l}\text { Abridged success criteria } \\
\text { (in order of importance) }\end{array}$} & \multirow{2}{*}{$\begin{array}{l}\text { Mean } \\
\text { importance }\end{array}$} & \multirow{2}{*}{$\begin{array}{l}\text { Mean } \\
\text { achievement }\end{array}$} & \multicolumn{4}{|c|}{ Factor loadings } \\
\hline & & & F1 & $\mathrm{F} 2$ & $\mathrm{~F} 3$ & $\mathrm{~F} 4$ \\
\hline Enjoyable work & 4.70 & 3.92 & 0.45 & - & - & - \\
\hline A personal sense of accomplishment & 4.52 & 3.53 & 0.63 & - & - & - \\
\hline Learning and developing skills & 4.45 & 3.75 & 0.50 & - & - & - \\
\hline Salary that provides a comfortable lifestyle & 4.38 & 3.71 & - & - & - & 0.71 \\
\hline Balance between work and nonwork & 4.32 & 3.62 & - & - & - & - \\
\hline Increasing financial rewards & 3.93 & 3.69 & - & - & - & 0.77 \\
\hline Surrounded by stimulating people & 3.91 & 3.52 & 0.60 & - & - & - \\
\hline Recognized by colleagues for expertise & 3.84 & 3.46 & - & - & 0.82 & - \\
\hline Developing relationships on the job & 3.76 & 3.63 & - & - & - & - \\
\hline Obtaining peer recognition & 3.70 & 3.41 & - & - & 0.67 & - \\
\hline Positions of increasing responsibility & 3.57 & 3.43 & - & 0.60 & - & - \\
\hline Personal autonomy & 3.52 & 3.20 & - & - & - & - \\
\hline Able to influence organizational direction & 3.32 & 2.35 & - & 0.60 & - & - \\
\hline Making a contribution to society & 3.26 & 2.77 & 0.41 & - & - & - \\
\hline Being in a position of authority & 2.86 & 3.29 & - & 0.83 & - & - \\
\hline Percentage of variance accounted for by factor & & & $23 \%$ & $9 \%$ & $5 \%$ & $4 \%$ \\
\hline
\end{tabular}

Note: Only factor loadings that account for more than $15 \%$ of variance $(\geq 0.40)$ are included. 
sitions of increasing responsibility, plus more intrinsic criteria such as enjoyable work and making a contribution to society. Factor analysis was used to examine the dimensionality of these criteria and to create scales to measure different facets of subjective success.

Consistent with models of person-organization fit, we asked respondents about both the importance of these 15 success criteria and whether or not they felt that they had achieved success on these criteria in their current work. Respondents were asked "How important is each of the following achievements to your definition of career success?" Items were phrased, for example, as "making a contribution to society." Response options ranged from "of little importance" to "very important." Respondents were then asked to reflect on the extent to which they felt that they had achieved these same criteria in their current work situation. The question was "To what extent do you agree or disagree with the following statements about your work?" In this case, the items were rephrased to reflect success on these criteria (e.g. "My job allows me to make a contribution to society"). Response options ranged from "disagree strongly" to "agree strongly." To assess the impact of congruence between employees' success criteria and what they had achieved, both importance and achievement of the criteria were included in the models predicting attitudes.

\subsubsection{Work attitudes}

Job satisfaction was measured using eight items based on the facet-specific scale developed by Quinn and Staines (1979) which includes items such as the job in general, the sorts of things done on the job, and current workload. Organizational commitment was assessed using eight items from Mowday et al. (1979). A sample item is "I really care about the fate of this organization." Intent to turnover was assessed using two items from Seashore et al. (1982). "I often think about quitting work with this organization" is a sample item.

\subsubsection{Objective success controls}

Three common indicators of objective success were included to serve as control variables. Organizational level was measured as the number of levels between the respondent and their CEO. Respondents also indicated the number of promotions they had received over the preceding five years. Salary was assessed by asking respondents to indicate their actual current salary or indicate the range within which it was contained. Range data were coded as the range mid-point to create a continuous variable for all respondents.

\section{Results}

\subsection{The subjective success criteria}

The mean importance and achievement score for each of the 15 criteria are shown in Table 1. A principal axis factor analysis of the success criteria importance scores identified four factors with Eigenvalues greater than one. These four factors together accounted for $42 \%$ of the variance in importance scores (see Table 1). All but three items (personal autonomy, developing relationships on the job, and maintaining a balance between work and nonwork) accounted for more than $15 \%$ of the variance (factor loadings $\geq 0.40$ ) and were included in the subsequent scales. The four resulting factors were fulfilling work (five items, $23 \%$ of variance), authority (three items, 9\% variance), recognition (two items, 5\% variance), and financial rewards (two items, 4\% variance). When the same four-factor model derived from the importance data was tested using the data for the achievement of these success criteria, confirmatory factor analysis indicated an acceptable model fit $($ RMSEA $=0.07$; Browne and Cudeck 1993; MacCallum et al. 1996). We created scale values by averaging the scores of the items which loaded on each of the factors.

Table 2 includes the means, standard deviations, reliabilities, and correlations for the scales of success importance and achievement plus the other independent and dependent variables. Where scales included only two items, the correlation of the two items has been reported in place of Cronbach's alpha. All of the scales exhibit reasonable to high reliability. The effect of the lower reliability and limited scope of some scales will be to attenuate correlations and thus make our tests more conservative. The importance scales for the success criteria were significantly correlated with each other but the correlations were low enough (highest $r=0.43$ ) to indicate that the criteria are conceptually distinct.

One possible threat to the validity of the achievement score data is the potential for contamination by cognitive consistency processes. The drive to reduce cognitive dissonance (Festinger 1957) may have led respondents to look at what they rated as important to them and to then claim that they had achieved it or vice versa. However, as can be seen from Table 2, the correlations between each success factor's achievement and its importance were relatively low (the highest was $r=0.27$ ). Thus, the achievement scores seem to reflect more than simple cognitive consistency processes.

\subsection{Subjective success and employee attitudes}

To test our hypotheses, each of the three attitudinal outcomes (job satisfaction, organizational commitment, and 


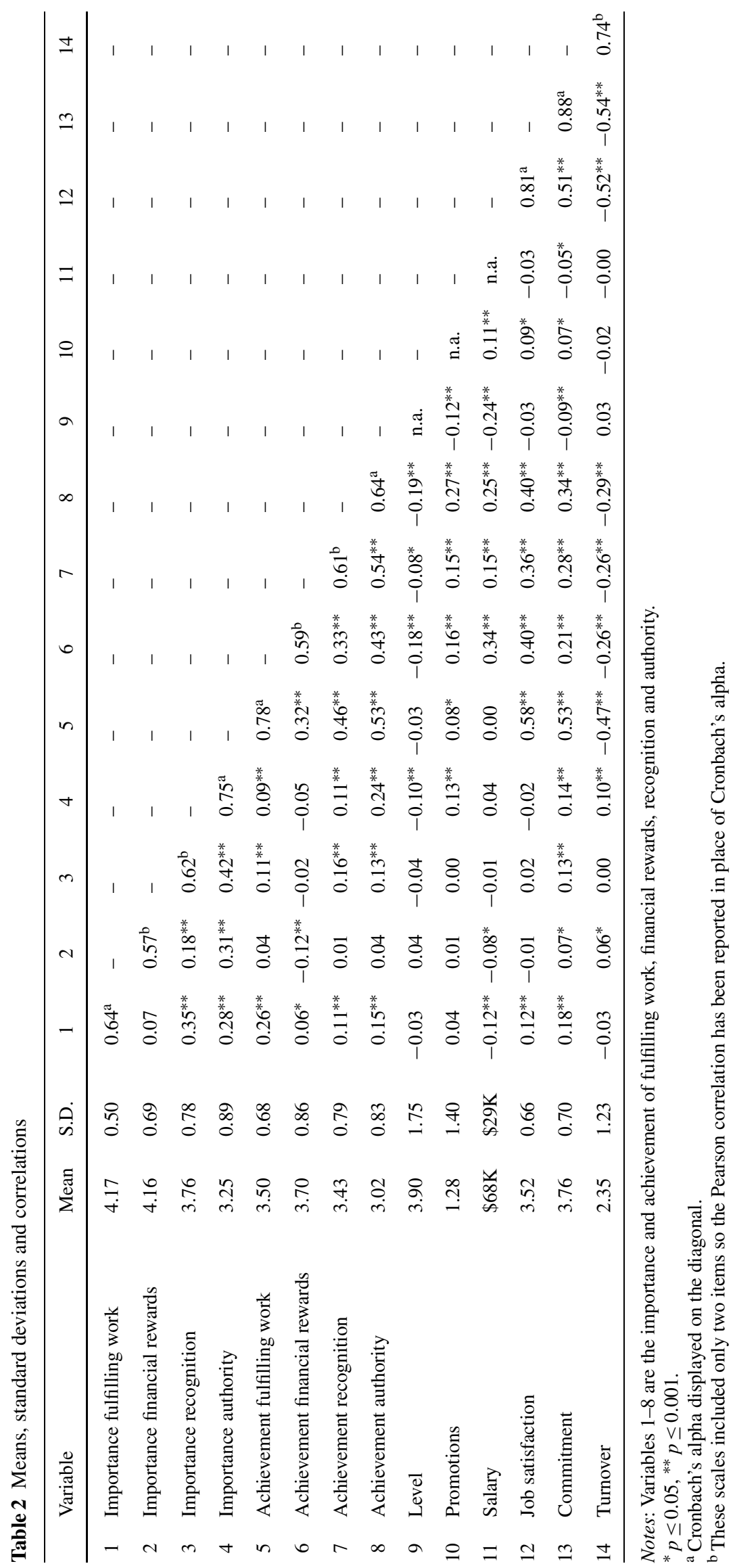


intent to turnover) was first regressed on the objective success measures (level, promotions, and salary). In the second step, the importance scores for the four subjective success factors were added to the equation. In the third step, the achievement scores for the four subjective success factors were added to the equation. As shown in Table 3, the objective success measures accounted for only small amounts of variance in job satisfaction (1\%) and organizational commitment $(2 \%)$. Objective success was not significantly related to turnover intentions. Similarly, in the second step, importance scores for the success criteria accounted for only small amounts of incremental variance in job satisfaction $(2 \%)$, commitment $(4 \%)$, and intent to turnover $(2 \%)$.

The achievement scores for the four success criteria, introduced in step 3, were a strong predictor of employee attitudes. In support of hypotheses H1-3, achievement of the four success criteria factors had a significant and substantial effect on job satisfaction $\left(\Delta R^{2}=0.40\right)$, commitment $\left(\Delta R^{2}=0.25\right)$, and turnover intentions $\left(\Delta R^{2}=0.24\right)$. The key predictor of all three attitudes was the achievement of fulfilling work. The achievement of financial rewards was the second most important predictor of attitudes although the standardized regression weights for financial rewards were significantly lower than those for fulfilling work.
Achievement of authority was significant for job satisfaction and turnover intention, not for commitment. Achievement of recognition only had an impact on job satisfaction. In total, the final model accounted for a significant portion of variance in job satisfaction $\left(R^{2}=0.42\right)$, commitment $\left(R^{2}=0.31\right)$, and intent to turnover $\left(R^{2}=0.26\right)$.

\section{Discussion}

\subsection{Subjective success}

The most significant finding of this research is the important role that achieving subjective success plays in employees' attitudes. The ability to achieve subjective success is substantially more important to attitudes than objective success. Achievement of subjective success criteria accounted for between $81 \%$ and $95 \%$ of the variance explained by our regression models ( $24 \%$ to $40 \%$ of total variance), despite the prior inclusion of objective success measures. This is a strong indicator of the role that achieving subjective success plays in the attitudes of employees. As one of the first studies to explore the potential attitudinal outcomes of subjective success, these findings lend support to Abele and Spurk's (2009a) call for greater research focus on the im-
Table 3 Hierarchical regression results

\begin{tabular}{|c|c|c|c|}
\hline Step and Statistic & $\begin{array}{l}\text { Job } \\
\text { satisfaction }\end{array}$ & $\begin{array}{l}\text { Organizational } \\
\text { commitment }\end{array}$ & $\begin{array}{l}\text { Turnover } \\
\text { intentions }\end{array}$ \\
\hline Step $1 R^{2}$ model & $0.01^{*}$ & $0.02^{* *}$ & 0.00 \\
\hline Step $1 \beta$ level & -0.02 & $-0.09^{*}$ & 0.02 \\
\hline Step $1 \beta$ promotions & $0.09^{*}$ & $0.08^{*}$ & -0.02 \\
\hline Step $1 \beta$ salary & -0.02 & $-0.07^{*}$ & -0.01 \\
\hline Step $2 R^{2}$ model & $0.03^{* *}$ & $0.05^{* *}$ & $0.02^{*}$ \\
\hline Step $2 \beta$ level & -0.02 & $-0.08^{*}$ & 0.03 \\
\hline Step $2 \beta$ promotions & $0.09^{*}$ & $0.07^{*}$ & -0.03 \\
\hline Step $2 \beta$ salary & 0.00 & -0.05 & -0.02 \\
\hline Step $2 \beta$ importance fulfilling work & $0.13^{* *}$ & $0.14^{* *}$ & -0.05 \\
\hline Step $2 \beta$ importance financial rewards & -0.01 & 0.03 & 0.04 \\
\hline Step $2 \beta$ importance recognition & 0.02 & 0.03 & -0.02 \\
\hline Step $2 \beta$ importance authority & $-0.07^{*}$ & $0.07^{*}$ & $0.12^{* *}$ \\
\hline Step $2 \Delta R^{2}$ importance subjective success & $0.02^{* *}$ & $0.04^{* *}$ & $0.02^{* *}$ \\
\hline Step $3 R^{2}$ model & $0.42^{* *}$ & $0.31^{* *}$ & $0.26^{* *}$ \\
\hline Step $3 \beta$ level & 0.02 & $-0.06^{*}$ & 0.01 \\
\hline Step $3 \beta$ promotions & 0.00 & 0.02 & 0.02 \\
\hline Step $3 \beta$ salary & $-0.14^{* *}$ & $-0.10^{* *}$ & $0.06^{*}$ \\
\hline Step $3 \beta$ importance fulfilling work & -0.03 & -0.01 & $0.09^{* *}$ \\
\hline Step $3 \beta$ importance financial rewards & 0.00 & 0.03 & 0.03 \\
\hline Step $3 \beta$ importance recognition & -0.01 & 0.04 & -0.03 \\
\hline Step $3 \beta$ importance authority & $-0.07^{*}$ & $0.06^{*}$ & $0.13^{* *}$ \\
\hline Step $3 \beta$ achievement fulfilling work & $0.43^{* *}$ & $0.46^{* *}$ & $-0.40^{* *}$ \\
\hline Step $3 \beta$ achievement financial rewards & $0.26^{* *}$ & $0.07^{*}$ & $-0.10^{* *}$ \\
\hline Step $3 \beta$ achievement recognition & $0.07^{*}$ & 0.01 & -0.02 \\
\hline Step $3 \beta$ achievement authority & $0.11^{* *}$ & 0.05 & $-0.09^{*}$ \\
\hline Step $3 \Delta R^{2}$ achievement subjective success & $0.40^{* *}$ & $0.25^{* *}$ & $0.24^{* *}$ \\
\hline
\end{tabular}

Note: Standardized regression weights $(\beta)$ are reported. ${ }^{*} p \leq 0.05,{ }^{* *} p \leq 0.001$. 
pact of subjective success. These results also have important implications for organizations. Identifying ways to enhance subjective success experiences will help to enhance job attitudes (job satisfaction, commitment, intention to stay at the organization) which in turn are related to job performance and voluntary turnover as meta-analyses demonstrate (Judge et al. 2001; Steel and Ovalle 1984; Tett and Meyer 1993).

The most important predictor of work attitudes was the subjective success scale that measured diverse aspects of fulfilling work such as a sense of personal accomplishment, being surrounded by stimulating people, learning and developing new skills, engaging in enjoyable work, and making a contribution to society. The impact of subjective success related to the achievement of financial rewards was also significant but considerably lower. The achievement of recognition had the least impact on attitudes; it affected only job satisfaction. This is an interesting finding because recognition was rated as more important, on average, than authority (mean importance 3.76 versus $3.25 ; t=22.15 ; p \leq 0.001$ ). One possible reason for this finding may be that recognition was easier to achieve than authority (mean achievement 3.43 versus $3.02 ; t=20.43 ; p \leq 0.001$ ). Another possible explanation of this finding is that recognition may be viewed as a characteristic of employee relationships rather than the organization and may consequently be unrelated to organizational commitment or turnover intentions.

The achievement scores explained significantly more variance in work attitudes than did the importance scores. This is consistent with the pattern of findings in some other congruence research where performance is a stronger predictor of satisfaction than is expectations (Page and Spreng 2002). These results suggest that while individuals may place different importance on various success criteria, in general their attitudes towards their job and their organization are influenced primarily by what they have achieved rather than the congruence between what they value and what they achieve. Future research may find that it is sufficient to use achievement scores alone rather than operationalizing both the importance and achievement of subjective success.

\subsection{Objective success}

The results suggest that objective success is not a strong predictor of job satisfaction, organizational commitment, or turnover intentions. In step one of the regression analysis, salary was unrelated to job satisfaction or turnover intentions, and negatively related to commitment $(\beta=-0.07)$. These results contradict prior research findings suggesting that higher salary is associated with greater job satisfaction (e.g. Green and Heywood 2008; Judge and Hurst 2008; Piero et al. 2010). One potential reason for these contradictory findings may be differences in job types or industry.
The relationship between pay and satisfaction may be stronger in mixed samples where pay is related to job type and industry. Respondents in our sample worked in similar jobs in the same industry and were relatively well paid. In this case, relative pay may be more important than absolute salary level. Our data show that subjective assessments of the achievement of financial rewards did have a significant impact on attitudes. This lends further support to the argument that researchers need to pay more attention to the subjective meaning of career attainments (Heslin 2005). These findings are also interesting in the context of the high-technology sector as the high-tech sector has relied extensively on monetary inducements to attract and retain employees during periods of growth (Lahey 1998).

In the full regression model, salary appears to act as a suppressor variable with respect to subjective success as indicated by its significantly larger beta when importance and achievement scores are included in the model (Cohen and Cohen 1983). Some methodologists view the inclusion of suppressor variables as a source of misleading results (e.g. Tabachnick and Fidell 1983) but researchers studying the effect of suppressor variables argue that they are important contributors to the development of knowledge and urge researchers to consider the joint impact of all predictors (Collins and Schmidt 1997; Friedman and Wall 2005; Rosenberg 1973). In order to assess the potential variance inflation resulting from the inclusion of a suppressor variable, the regression analysis was rerun excluding the salary variable. There was a $1 \%$ decline in the total variance explained in each of the models but the pattern of results was substantially the same when salary was excluded from the analysis. Thus, the suppression effects do not affect the substantive conclusions.

\subsection{Limitations}

Our study has a number of limitations. First, the focus on a relatively mobile and privileged sample may limit the generalizability of the findings. In other settings, for instance, the achievement of subjective success may have less of an impact on turnover intentions because of restricted opportunities. Second, the use of a common questionnaire method to measure both the independent and dependent variables can potentially bias the results. Third, the study is limited by its reliance on self-report data. While subjective success must necessarily be studied using self-reports, non-self-report measures of objective success would have enhanced the validity of the findings. Finally, another potential limitation is the response rate of $37 \%$. This is lower than the average response rates reported in reviews of research on professionals (59\%) and managers $(62 \%$, Baruch 1999) but higher than those reported for senior managers (28\%, Cycyota and Harrison 2006). 


\subsection{Implications and conclusions}

The substantial impact which subjective success has on attitudes suggests that future researchers may want to examine in more detail what employers can do to facilitate employee subjective success. Researchers may also want to explore other potential impacts of subjective success such as motivation and job performance. Given the importance our respondents attached to fulfilling work, further exploration of this construct and its antecedents would be a fruitful avenue for future research. More research on the desire for and implications of receiving recognition would also be helpful to shed light on the results regarding recognition. It may also be beneficial to explore the impact that individual differences such as gender, age and life cycle stage have on subjective career success.

The results from this study suggest that money is not the only, or best, way to meet employees' aspirations for success. On the basis of the present results, actual salary appears to be less important to employees - at least to well-paid employees in the high-tech industry - than their subjective evaluation of their financial rewards and significantly less important than achieving fulfilling work. Together the results highlight the importance to both researchers and organizations of developing a better understanding of the meaning of subjective success.

\section{Executive summary}

Success is a key outcome in an individual's career. Subjective success represents an individual's self-evaluation of her or his success. Research suggests that subjective success is related to but broader than objective indicators of success such as hierarchical position and financial rewards. Subjective success may also include criteria such as relationships, balance, enjoyment, and recognition.

Past research on subjective success has focused largely on the antecedents of subjective success and sought to determine what makes people evaluate their careers positively. Very few studies have explored the link between subjective career success and key organizational attitudes. This is unfortunate as research on person-environment fit would suggest that employees are more likely to report positive attitudes towards their work and their organization when there is a fit between their definitions of subjective career success and their career achievements. The present study examined the impact that attainment of subjective career success has on three key employee attitudes toward their work and organization: job satisfaction, organizational commitment, and intent to turnover.

Data were collected from 1,509 managers and professionals in Canada's high-tech sector. The average age of respon- dents was 36 and two thirds were men. Most were married and half had children. Post-secondary education was almost universal. Respondents had an average of 12 years of work experience with 9 years of that in the high-tech sector. Over half worked in product development, engineering, or programming. Almost two thirds were in professional or technical roles; just under a third managed the work of others. Respondents worked an average of $46 \mathrm{~h}$ per week.

Four dimensions of subjective success were measured: fulfilling work, financial rewards, recognition, and authority. Respondents indicated how important each success criteria was to their personal definition of success and also indicated to what extent they felt they had achieved success on that dimension. Hierarchical regression models predicting job satisfaction, commitment, and turnover were examined. Objective indicators of success (organizational level, promotions, and salary) were included as control variables along with importance scores and achievement scores for each of the success criteria.

Results indicated that the ability to achieve subjective success was substantially more important to attitudes than objective success. Achievement of subjective success criteria accounted for between $81 \%$ and $95 \%$ of the variance explained by the regression models (24\% to $40 \%$ of total variance), despite the prior inclusion of objective success measures. These results suggest that identifying ways to enhance employee subjective success experiences will help to enhance job satisfaction, commitment, and intent to stay at the organization, which other research has shown to influence job performance and voluntary turnover.

The most important predictor of work attitudes was the subjective success scale that measured diverse aspects of fulfilling work such as a sense of personal accomplishment, being surrounded by stimulating people, learning and developing new skills, engaging in enjoyable work, and making a contribution to society. The impact of subjective success related to the achievement of financial rewards was also significant but considerably lower. The results from this study suggest that money is not the only, or best, way to meet employees' aspirations for success. On the basis of the present results, actual salary appears to be less important to employees - at least to well-paid employees in the high-tech industry - than their subjective evaluation of their financial rewards and significantly less important than achieving fulfilling work. Together the results highlight the importance to both researchers and organizations of developing a better understanding of the meaning of subjective success.

\section{Kurzfassung}

Erfolg ist ein Schlüsselergebnis im Berufsleben jedes Individuums. Der subjektive Erfolg stellt die individuelle Selbst- 
bewertung des eigenen Erfolgs dar. Forschungsergebnisse zeigen, dass der subjektiv Erfolg zwar möglicherweise in Beziehung mit objektiven Erfolgsindikatoren wie der Stellung in einer Hierarchie oder finanziellem Erfolg steht, jedoch breiter gestaltet ist. Der subjektive Erfolg kann ebenfalls Kriterien wie Beziehungen, Ausgeglichenheit, Freude und Anerkennung beinhalten.

Frühere Forschung zum Thema subjektiver Erfolg befasste sich vorwiegend mit den Bedingungen des subjektiven Erfolgs und ging der Frage nach, welche Faktoren Menschen dazu bewegen, die eigene Karriere positiv zu bewerten. Nur wenige Studien haben die Verbindung zwischen dem subjektiven Berufserfolg und der Einstellung gegenüber der Organisation untersucht. Dies ist bedauerlich, da Forschungsarbeiten über „Person-Environment-Fit“ (Übereinstimmung zwischen Person und Arbeitsumgebung) darauf hindeuten, dass Mitarbeiter eher über positive Einstellungen zu ihrer Arbeit und ihrer Organisation berichten, wenn ihre eigene Definition von subjektiven Berufserfolg und ihr tatsächlicher beruflicher Erfolg übereinstimmen. Mit der vorliegenden Studie wird untersucht, wie sich das Erreichen von subjektivem Berufserfolg auf drei zentrale Einstellungen von Mitarbeitern zu ihrer Arbeit und Organisation auswirkt- die Arbeitszufriedenheit, die organisationale Bindung und die Absicht, die Arbeit zu wechseln.

Daten wurden von 1.509 Führungs- und Fachkräften im kanadischen High-Tech-Sektor gesammelt. Das Durchschnittsalter unter den Teilnehmern betrug 36 und zwei Drittel waren Männer. Die Mehrheit war verheiratet und die Hälfte hatten Kinder. Alle hatten eine weiterführende Ausbildung. Die Teilnehmer hatten im Durchschnitt 12 Jahre Berufserfahrung und 9 davon im High-Tech-Sektor. Mehr als die Hälfte waren in der Produktentwicklung, im Technikbereich oder in der Programmierung tätig. Beinahe zwei Drittel hatten fachmännische oder technikbezogene Positionen; knapp weniger als ein Drittel der Teilnehmer hatten Mitarbeiter zu leiten. Die Durchschnittsarbeitswoche betrug 46 Stunden.

Vier Dimensionen des subjektiven Erfolgs wurden bewertet: erfüllende Arbeit, finanzielle Belohnungen, Anerkennung und Autorität. Die Teilnehmer gaben an, wie wichtig jedes Erfolgskriterium für die persönliche Definition des Erfolgs ist („Importance-Scores“) und auch für wie erfolgreich sie sich in Bezug auf jedes Kriterium hielten („Achievement-Scores“). Hierarchische Regressionsmodelle, die die Arbeitszufriedenheit, das Engagement/die organisationale Bindung und den Arbeitgeberwechsel voraussagen, wurden untersucht. Objektive Erfolgsindikatoren (die Stellung in der Hierarchie, Beförderungen und Bezahlung) wurden zusammen mit den Importance- und AchievementScores für jedes Erfolgskriterium als Kontrollvariablen ebenfalls berücksichtigt.
Die Ergebnisse deuteten darauf hin, dass die Fähigkeit, subjektiven Erfolg zu erlangen, den Teilnehmern wesentlich wichtiger war als der objektive Erfolg. Trotz des Miteinbeziehens von objektiven Erfolgskriterien waren zwischen $81 \%$ und 95\% der durch die Regressionsmodelle festgestellten Varianz (24\% bis $40 \%$ der Gesamtvarianz) dem Erlangen von subjektiven Erfolgskriterien zuzuschreiben. Diesen Ergebnissen zufolge würde eine Verbesserung bzw. Steigerung von subjektiven Erfolgserlebnissen unter Mitarbeitern auch eine Steigerung der Arbeitszufriedenheit, des Engagements und der Bereitschaft, den Arbeitgeber nicht zu wechseln, bedeuten - Faktoren, die, wie in anderen Forschungsarbeiten belegt, die Arbeitsleistung und den freiwilligen Arbeitgeberwechsel beeinflussen.

Der wichtigste Indikator für Arbeitseinstellungen war die subjektive Erfolgsskala, die diverse Aspekte der erfüllenden Arbeit maß. Dazu gehörten das Gefühl der persönlichen Leistung; die Zusammenarbeit mit stimulierenden Menschen; das Erlernen und die Entwicklung von neuen Fähigkeiten; eine interessante und angenehme Arbeit; und das Gefühl, zur Gesellschaft etwas beizutragen. Auf finanzielle Belohnungen bezogene subjektive Erfolgsaspekte waren ebenfalls signifikant, aber erheblich weniger wichtig. Aus den Ergebnissen dieser Studie geht hervor, dass Geld weder die einzige noch die beste Möglichkeit ist, die Erfolgserwartungen der Mitarbeiter zu erfüllen. Den Ergebnissen zufolge scheint für Mitarbeiter - zumindest für gutbezahlte Mitarbeiter im High-Tech-Sektor - die Bezahlung weniger wichtig zu sein als die eigene subjektive Einschätzung der finanziellen Belohnung und erheblich weniger wichtig als eine erfüllende Arbeit. Zusammengenommen unterstreichen die Ergebnisse die Wichtigkeit für Forscher und Organisationen, ein besseres Verständnis der Bedeutung des subjektiven Erfolgs zu entwickeln.

Acknowledgements This paper was originally presented to the LASER-IAB International Workshop on Career Success - Approaches from Economics and Psychology in Nuremberg, Germany, December 2009. Funding for this research was provided by the Human Resources Research Institute of Canada. The authors wish to thank the special issue editor Andrea Abele-Brehm and two anonymous reviewers for their helpful feedback on this manuscript.

\section{References}

Abele, A.E., Spurk, D.: How do objective and subjective career success interrelate over time? J. Occup. Organ. Psych. (2009a). doi:10.1348/096317909X470924

Abele, A.E., Spurk, D.: The longitudinal impact of self-efficacy and career goals on objective and subjective career success. J. Vocat. Behav. (2009b). doi:10.1016/j.jvb.2008.10.005

Bailyn, L.: Understanding individual experience at work: comments on the theory and practice of careers. In: Arthur, M.B., Hall D.T., Lawrence B.S. (eds.) Handbook of Career Theory, pp. 477-489. Cambridge University Press, New York (1989) 
Baruch, Y.: Response rate in academic studies - a comparative analysis. Hum. Relations 52(4), 421-438 (1999)

Browne, M.W., Cudeck, R.: Alternative ways of assessing model fit. In: Bollen, K.A., Long. J.S. (eds.) Testing Structural Equation Models, pp. 136-162. Sage, Newbury Park (1993)

Caplan, R.D., Harrison, R.V.: Person-environment fit theory: some history, recent developments, and future directions. J. Soc. Issues $\mathbf{4 9}$, 253-275 (1993)

Cohen, J., Cohen, P.: Applied Multiple Regression/Correlation Analysis for the Behavioral Sciences, 2nd edn. Lawrence Erlbaum, Hillsdale (1983)

Collins, J.M., Schmidt, F.L.: Can suppressor variables enhance criterion-related validity in the personality domain. Educ. Psychol. Meas. 57(6), 924-936 (1997)

Cycyota, C.S., Harrison D.A.: What (not) to expect when surveying executives: a meta-analysis of top manager response rates and techniques over time. Organ. Res. Methods (2006). doi: $10.1177 / 1094428105280770$

Dawis, R.V., Lofquist, L.H.: A Psychological Theory of Work Adjustment. University of Minnesota Press, Minneapolis (1984)

Deci, E.L., Ryan, R.M.: The "what" and "why" of goal pursuits: human needs and the self-determination of behaviour. Psychol. Inq. 11(4), 227-268 (2000)

Dyke, L.S., Murphy, S.A.: How we define success: a qualitative study of what matters most to women and men. Sex Roles (2006). doi:10.1007/s11199-006-9091-2

Edwards, J.R.: The study of congruence in organizational behavior research: critique and a proposed alternative. Organ. Behav. Hum. Dec. 58, 51-100 (1994)

Erdogan, B., Kraimer, M.L., Liden, R.C.: Work value congruence and intrinsic career success: the compensatory roles of leader-member exchange and perceived organizational support. Pers. Psychol. 57, 305-332 (2004)

Festinger, L.: A Theory of Cognitive Dissonance. Stanford University Press, California (1957)

Friedman, L., Wall, M.: Graphical views of suppression and multicollinearity in multiple linear regression. Am. Stat. (2005). doi:10.1198/000313005X41337

Gattiker, U.E., Larwood, L.: Subjective career success: a study of managers and support personnel. J. Bus. Psychol. 1(2), 78-94 (1986)

Glisson, C., Durick, M.: Predictors of job satisfaction and organizational commitment in human service organizations. Admin. Sci. Quart. 33, 61-81 (1988)

Green, C., Heywood, J.S.: Does performance pay increase job satisfaction? Economica 75, 710-728 (2008)

Gunz, H.P., Heslin, P.A.: Reconceptualizing career success. J. Organ. Behav. 26, 105-111 (2005)

Herzberg, F., Mausner, B., Snyderman, B.: The Motivation to Work. Wiley, New York (1959)

Heslin, P.A.: Conceptualizing and evaluating career success. J. Organ. Behav. 26(2), 113-136 (2005). doi:10.1002/job.270

Judge, T.A., Bretz, R.D.: Political influence behavior and career success. J. Manage. 20(1), 43-65 (1994)

Judge, T.A., Cable, D.M., Boudreau, J.W., Bretz, R.D.: An empirical investigation of the predictors of executive career success. Pers. Psychol. 48, 485-519 (1995)

Judge, T.A., Hurst, C.: How the rich (and happy) get richer (and happier): relationship of core self-evaluations to trajectories in attaining work success. J. Appl. Psychol. 93(4), 849-863 (2008)

Judge, T.A., Thoresen C.J., Bono J.E., Patton G.K.: The job satisfaction-job performance relationship: a qualitative and quantitative review. Psychol. Bull. 127(3), 376-407 (2001)

Kristof, A.L.: Person-organization fit: an integrative review of its conceptualizations, measurement, and implications. Pers. Psychol. 49(1), 1-49 (1996)
Kristof-Brown, A.L., Zimmerman R.D., Johnson, E.C.: Consequences of individuals' fit at work: a meta-analysis of person-job, personorganization, person-group, and person-supervisor fit. Pers. Psychol. 58, 281-342 (2005)

Lahey, A.: The most popular guys in the world. Can. Bus. 71(16), 94-100 (1998). Retrieved 15 Nov 2010, from CBCA Business (document ID: 34890540)

Locke, E.A.: The nature and causes of job satisfaction. In: Dunette, M.D. (ed.) Handbook of Industrial and Organizational Psychology, pp. 1297-1349. McGraw-Hill, New York (1976)

MacCallum, R.C., Browne, M.W., Sugawara, H.M.: Power analysis and determination of sample size for covariance structure modeling. Psychol. Methods 1(2), 130-149 (1996)

Mowday, R., Porter, L., Steers, R.: Organizational Linkages: The Psychology of Commitment, Absenteeism, and Turnover. Academic, New York (1982)

Mowday, R., Steers, R., Porter, L.: The measurement of organizational commitment. J. Vocat. Behav. 14, 224-247 (1979)

Nabi, G.R.: The relationship between HRM, social support and subjective career success among men and women. Int. J. Manpower 22, 457-474 (2001)

Ng, T.W.H., Eby, L.T., Sorensen, K.L., Feldman, D.C.: Predictors of objective and subjective career success: a meta-analysis. Pers. Psychol. 58, 367-408 (2005)

O'Reilly, C., Chatman, J.: Organizational commitment and psychological attachment: the effects of compliance, identification, and internalization on prosocial behavior. J. Appl. Psychol. 71(3), 492-499 (1986)

Page, T.J., Spreng, R.A.: Difference scores versus direct effects in service quality measurement. J. Serv. Res. (2002). doi:10.1177/ 1094670502004003002

Peluchette, J.V.E.: Subjective career success: the influence of individual difference, family, and organizational variables. J. Vocat. Behav. 43, 198-208 (1993)

Piero, J.M., Agut, S., Grau, R.: The relationship between overeducation and job satisfaction among young Spanish workers: the role of salary, contract of employment, and work experience. J. Appl. Psychol. 40(3), 666-689 (2010)

Quinn, R.P., Staines, G.L.: The 1977 Quality of Employment Survey. Institute for Social Research, University of Michigan, Ann Arbor, MI (1979)

Rosenberg, M.: The logical status of suppressor variables. Public Opin. Quart. 37(3), 359-372 (1973)

Schneider, B.: The people make the place. Pers. Psychol. 40, 437-453 (1987)

Seashore, S.E., Lawler, E.E., Mirvis, P., Cammann, C.: Observing and Measuring Organizational Change: a Guide to Field Practice. Wiley, New York (1982)

Spector, P.E.: Job Satisfaction: Application, Assessment, Causes, and Consequences. Sage, Thousand Oaks (1997)

Steel, R.P., Ovalle, N.K.: A review and meta-analysis of research on the relationship between behavioral intentions and employee turnover. J. Appl. Psychol. 69(4), 673-686 (1984)

Sturges, J.: What it means to succeed: personal conceptions of career success held by male and female managers at different ages. Brit. J. Manage. 10, 239-252 (1999)

Tabachnick, B.G., Fidell, L.S.: Using Multivariate Statistics. Harper and Row, New York (1983)

Tett R.P., Meyer J.P.: Job satisfaction, organizational commitment, turnover intention, and turnover: path analyses based on meta-analytic findings. Pers. Psychol. 46, 259-293 (1993)

Dr. Lorraine Dyke is an Associate Professor in the Sprott School of Business at Carleton University. She is also the founder and current Director of the Center for Research and Education on Women and Work. 
Dr. Dyke's research focuses on careers, the changing workplace and workforce diversity. Her monographs include a cross-cultural study of attitudes towards women in management, a study on career development in the federal public service and a study of career issues in the high-tech sector. She is the author of numerous research articles and the recipient of several research awards. She has worked with some of Canada's largest public and private sector organizations.

e-mail: lorraine_dyke@carleton.ca

Dr. Linda Duxbury is a Professor at the Sprott School of Business, Carleton University. Within the past decade she has completed major studies on Balancing Work and Family in the public, private, not for profit and small business sectors; Management Support; Career Development in the Public and High-Tech sectors; and generational differences in work values.

Dr. Duxbury has published widely in both the academic and practitioner literature in the areas of work-family conflict, change management, supportive work environments, stress, telework, the use and impact of office technology, managing the new workforce, labor force demographics, generational cohorts, and supportive management.

Dr. Duxbury has received numerous awards for both her research and teaching.

e-mail: linda_duxbury@carleton.ca 